\title{
Purification and Characterization of the Alkaline Serine Protease Produced by Bacillus sp. N4 Strain from Fish Skin Mucus
}

\author{
Makio Asakawa, ${ }^{* 1, \dagger}$ Yoshiko Sadakata, ${ }^{* 1}$ Toshiyoshi Araki, ${ }^{* 2}$ Toshihisa Sumi, ${ }^{* 3}$ \\ and Hiroki Nakagawa*3 \\ ${ }^{* 1}$ Laboratory of Food Science, Faculty of Education, Kumamoto University, Kumamoto 860-8555, \\ Japan \\ ${ }^{* 2}$ Faculty of Bioresources, Mie University, Kamihama, Tsu 514-8507, Japan \\ *3Department of Applied Biological Sciences, Faculty of Agriculture, Saga University, Honjyo, \\ Saga 840-8502, Japan
}

(Received December 15, 1997)

\begin{abstract}
Bacillus sp. N4 strain was isolated from the skin mucus of horse mackerel Trachurus japonicus. A protease was purified to homogeneity from the culture fluid by application of ammonium sulfate precipitation, gel filtration, and ion-exchange chromatography. The enzyme (N4-protease) had a single polypeptide chain with apparent molecular weight of 28,000 estimated by SDS-PAGE, and an isoelectric point around 9.5. The enzyme was most active toward azocasein and Suc-Leu-Leu-Val-Tyr-MCA at $\mathrm{pH} 10$ and toward casein at $\mathrm{pH} 11$, and was stable between $\mathrm{pH} 6$ and $\mathrm{pH} 11$. The optimum temperature of the enzyme was $50^{\circ} \mathrm{C}$ and its activity was stable below $50^{\circ} \mathrm{C}$. Calcium ion was effective to activate and stabilize the enzyme especially at high temperature. Since the activity was completely inhibited by PMSF and DFP but not by sulfhydryl and metal chelating agents, it was concluded that N4-protease is an alkaline serine protease belonging to a member of the subtilisin family.
\end{abstract}

Key words: Bacillus sp. N4 strain, alkaline serine protease, fish skin mucus, horse mackerel, Flavobacterium sp.

Densities and composition of the microflora on fish skin reflect variations in the bacterial population of the environment in which they inhabit. Large numbers of bacteria are usually found on the skin $\left(10^{2}-10^{7} / \mathrm{cm}^{2}\right)$ and the gill tissue $\left(10^{3}-10^{6} / \mathrm{g}\right)$, and in the intestinal fluid $\left(10^{3}-10^{8} / \mathrm{m} l\right)$ of live and freshly caught marine fishes. ${ }^{1)}$ These bacteria penetrate into fish flesh through the gill tissue, intestines, and skin mucus after the death of fishes, and fish spoilage is advanced by the invasion of such bacteria. Among these, the epiphytic bacteria on fish skin covered with mucus play a major role in the degree of freshness and the spoilage of fishes as foodstuffs. It is considered that these epiphytic bacteria produce extracellular enzymes, which are involved in decomposition of the skin mucous components such as proteins, glycoproteins, polysaccharides, lipids, and other materials secreted from the epithelial cells.

In the present study, an attempt was made to isolate protease-producing bacteria from the skin mucus of horse mackerel Trachurus japonicus and to characterize an extracellular protease of an isolate Bacillus sp. N4 strain.

\section{Materials and Methods}

\section{Materials}

An authentic substrate, Suc-Leu-Leu-Val-Tyr-MCA was manufactured by Peptides Institute, Inc. (Osaka,
Japan). Azocasein, DFP, and PMSF were supplied from Sigma Chemical Co. (St. Louis, Mo., U.S.A.). Pharmalyte (pH 3.5-10), Sephadex G-50 (fine), Superdex G-75 $P G$, and standard proteins for SDS-PAGE were from Pharmacia Fine Chemicals (Uppsala, Sweden). CMToyopearl 650S was produced by Toyo Soda Co. (Tokyo, Japan). Polypeptone, yeast extract, and other chemicals were from Nacalai Tesque, Inc. (Kyoto, Japan).

\section{Medium}

An isolation medium (PY-medium, pH 7.4) was composed of $0.5 \%$ polypeptone, $0.1 \%$ yeast extract and $0.5 \%$ or $3 \% \mathrm{NaCl}$. This medium was also used for an agar slant culture after solidifying with $1.8 \%$ agar.

\section{Screening of protease-producing bacteria}

Fresh horse mackerel Trachurus japonicus caught at Amakusa, Kumamoto Prefecture, were purchased from a fish market. The skin mucus, scraped carefully off the body surface with the aid of an aseptic knife, was suspended in a small volume of sterile $0.9 \% \mathrm{NaCl}$ solution. A small quantity of the suspension was streaked to the surface of the agar plates containing $0.5 \%$ and $3 \% \mathrm{NaCl}$, and the inoculated media were aerobically incubated at $25^{\circ} \mathrm{C}$. After incubation for 2-4 days, the well-grown and apparently different types of colonies were carefully isolated.

t To whom correspondence should be addressed. Abbreviations: Suc-Leu-Leu-Val-Tyr-MCA, succinyl-Leu-Leu-Val-Tyr-4-methylcoumaryl-7. To whom correspondence should be addressed. Abbreviations: Suc-Leu-Leu$N^{\alpha}$-tosyl-L-lysyl chloromethyl ketone; PCMB, $\rho$-chloromercuribenzoic acid; EGTA, ethyleneglycol bis(2-aminoethylether)-N, $N, N^{\prime}, N^{\prime}$-tetraacetic acid; NEM, $N$-ethylmaleimide 
Each colony was transferred into $30 \mathrm{~m} l$ of the PY-medium in a $100-\mathrm{m} l$ Erlenmeyer flask with silicon plug. After incubation at $25^{\circ} \mathrm{C}$ for 2 days with mechanical shaking at 90 $\mathrm{rpm}$, each culture was centrifuged at $17,000 \times \mathrm{g}$ for $30 \mathrm{~min}$ at $5^{\circ} \mathrm{C}$. The supernatant was subjected to assay for protease activity at pHs 5.0 and 8.5 by the method as described later. Two strains (N4 and N9) were finally selected as the most potent producers of protease, and strain N4 was used in the present study.

\section{Cultivation}

Strain N4 from an agar slant culture was incubated in 50 $\mathrm{m} l$ of PY-medium containing $0.5 \% \mathrm{NaCl}$ at $25^{\circ} \mathrm{C}$ for $24 \mathrm{~h}$ with shaking. Then the culture was transferred to a siliconplugged 3-liter Erlenmeyer flask containing 1 liter of the same medium containing $0.1 \% \mathrm{CaCl}_{2}$ as a stabilizer, and the medium was incubated for $40-48 \mathrm{~h}$ at $25^{\circ} \mathrm{C}$ with shaking. The growth was monitored by reading turbidity at $630 \mathrm{~nm}$.

\section{Purification of protease}

Unless otherwise indicated, all operations were carried out at $5^{\circ} \mathrm{C}$. Centrifugations were routinely done at $17,000 \times \mathrm{g}$ for $30 \mathrm{~min}$ at $2^{\circ} \mathrm{C}$ in a Hitachi $18 \mathrm{PR}-3$ refrigerated centrifuge (Hitachi Ltd., Tokyo, Japan). The supernatant (1 liter) obtained by centrifugation of the culture medium of N4 strain was subjected to reverse dialysis by addition of solid ammonium sulfate to $75 \%$ saturation overnight. The resulting precipitate was collected by centrifugation as a crude protease.

The precipitate obtained was dissolved in $30 \mathrm{~m} l$ of 20 $\mathrm{mM}$ Tris-HCl buffer (pH 7.0) containing $5 \mathrm{mM} \mathrm{CaCl}_{2}$ and the solution was applied to a column $(2.6 \times 110 \mathrm{~cm})$ of Sephadex G-50 (fine grade) previously equilibrated with the same buffer. The fractions exhibiting protease activity were pooled, concentrated to a small volume by ultrafiltration (PM-10 membrane, Amicon Corporation, U.S.A.), and dialyzed against $10 \mathrm{~mm}$ sodium phosphate $(\mathrm{pH} 7.0$ ) overnight.

A dialyzed sample was applied to a CM-Toyopearl 650S column $(1.6 \times 20 \mathrm{~cm})$ previously equilibrated with $10 \mathrm{mM}$ sodium phosphate ( $\mathrm{pH} 7.0$ ). The protease retained by the column was eluted with a linear $\mathrm{NaCl}$ gradient from 0 to $0.3 \mathrm{M}$ in the same buffer. The fractions exhibited protease activity were pooled and concentrated by ultrafiltration.

The sample was finally purified by chromatography on a column $(1.6 \times 75 \mathrm{~cm})$ of Superdex $75 \mathrm{PG}$ with $50 \mathrm{~mm}$ Tris$\mathrm{HCl}, \mathrm{pH} 7.0$, containing $5 \mathrm{mM} \mathrm{CaCl}_{2}$. The active fractions were concentrated by ultrafiltration and stored at $-30^{\circ} \mathrm{C}$ until use. This preparation was referred to as N4-protease.

\section{Assay of protease activity}

The activity in the fractions obtained at each step of purification was assayed as follows: To $0.5 \mathrm{~m} /$ of suitably diluted enzyme solution were added $1.0 \mathrm{~m} /$ of $0.1 \mathrm{M}$ sodium carbonate-bicarbonate buffer $(\mathrm{pH} \mathrm{10.0)}$ and $0.5 \mathrm{~m} l$ of $0.5 \%$ azocasein solution. The mixture was incubated at $37^{\circ} \mathrm{C}$ for $20 \mathrm{~min}$ and then the reaction was stopped by addition of $0.5 \mathrm{~m} l$ of $25 \%$ trichloroacetic acid solution. After standing for $10 \mathrm{~min}$ at $5^{\circ} \mathrm{C}$, the mixture was centrifuged at $2,300 \times g$ for $10 \mathrm{~min}$ and the supernatant was photometrically measured at $400 \mathrm{~nm}$. One unit of enzyme activity was defined as the amount of enzyme which increases the absor- bance 0.001 at $400 \mathrm{~nm}$ per min under the conditions described above.

\section{Fluorometric assay}

Enzyme assay was carried out in a mixture of $5 \mu l$ of 10 mM Suc-Leu-Leu-Val-Tyr-MCA in dimethylsulfoxide and $450 \mu l$ of Carmody's wide-range buffer. ${ }^{2)}$ The reaction was started by addition of $50 \mu l$ of the enzyme solution. After incubation for $10 \mathrm{~min}$ at $37^{\circ} \mathrm{C}$, the amount of 7-amino-4methylcoumarin released from the substrate was measured with excitation at $380 \mathrm{~nm}$ and emission at $441 \mathrm{~nm}$ by using a fluorescence spectrophotometer (Model 650-10S, Hitachi Ltd., Tokyo, Japan) equipped with a recorder.

\section{Isoelectric focusing}

Isoelectric focusing was performed on a Rotofor apparatus (Bio-Lad Laboratories, Richmond, Ca., U.S.A.) with $1 \%$ Pharmalyte (pH range $3.5-10$ ) at $4{ }^{\circ} \mathrm{C}$ for $4 \mathrm{~h}$. The protease activity in the collected fractions was assayed by the method as described above. The $\mathrm{pH}$ gradient was measured by using a pH-meter (Type F-13, Horiba Ltd., Tokyo, Japan) at room temperature.

\section{Effects of inhibitors and metal ions}

The effects of inhibitors and metal ions on the N4-protease activity were examined by measuring the remaining activity using azocasein as a substrate after preincubation of the enzyme with chemicals in $50 \mathrm{~mm}$ sodium carbonatebicarbonate buffer $(\mathrm{pH} 10.0)$ at $37^{\circ} \mathrm{C}$ for $30 \mathrm{~min}$.

\section{Analytical methods}

Protein was determined by the method of Lowry et al. ${ }^{3)}$ with bovine serum albumin as a standard. SDS-PAGE was done by the method of Laemmli ${ }^{4)}$ using a $12 \%$ slab gel containing $0.1 \%$ SDS at $20 \mathrm{~mA}$. The enzyme was pretreated with or without 2-mercaptoethanol before SDS-PAGE. Gels were stained for protein with Coomassie brilliant blue R-250.

\section{Results}

\section{Identification of N4 strain}

The isolated strain N4 was an aerobic, Gram positive, spore-forming, catalase positive, oxidase negative, and rod-shaped bacterium (0.6-0.7 $\mu \mathrm{m} \times 1.8-2.0 \mu \mathrm{m})$ and grew well in PY-medium containing $0.5 \%$ and $3 \% \mathrm{NaCl}$. It was clear that the isolate belongs to the genus Bacillus according to the criteria described in Bergey's Manual of Systematic Bacteriology. ${ }^{5)}$ This strain was tentatively named as Bacillus sp. N4 strain, which was used in the present study.

\section{Growth and protease production}

Bacillus sp. N4 strain was cultivated in PY-medium up to $48 \mathrm{~h}$ at $25^{\circ} \mathrm{C}$ with gentle shaking. As shown in Fig. 1, the protease activity was detected after $10 \mathrm{~h}$ of cultivation at the beginning of the logarithmic growth phase, and the production reached a maximum level at the stational growth phase.

\section{Purity and molecular weight}

N4-protease was purified from the culture supernatant 


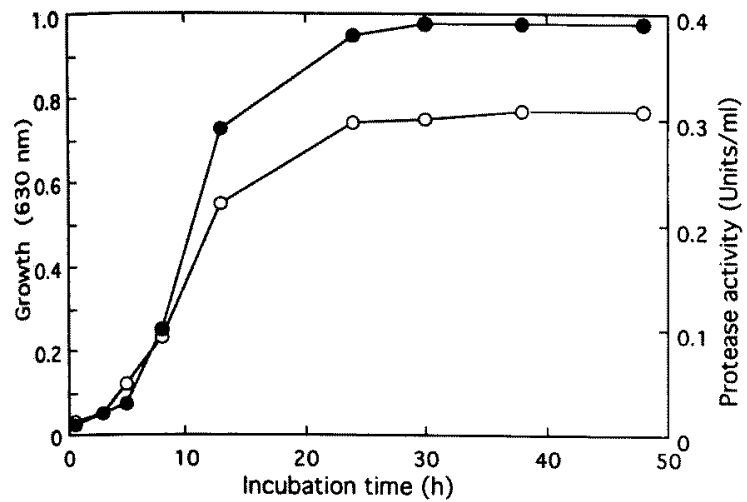

Fig. 1. Growth curve of Bacillus sp. N4 strain and its production of protease.

0 , growth; $\bullet$, protease activity.

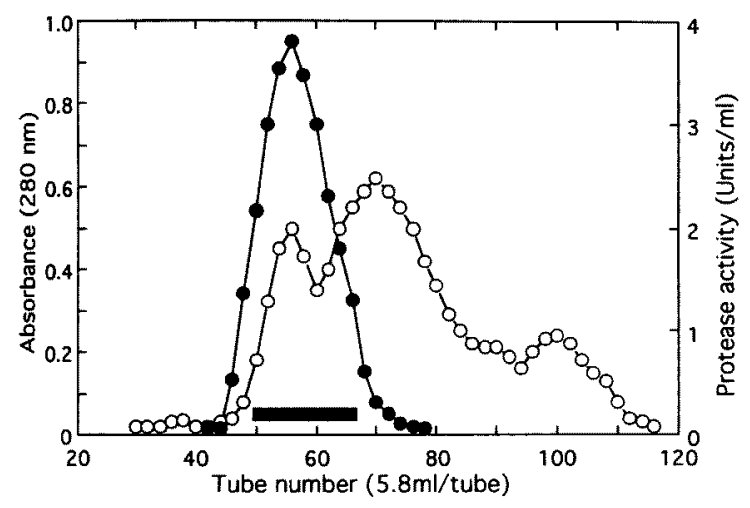

Fig. 2. Gel filtration of N4-protease.

The crude protease $(30 \mathrm{~m} /)$ was put on a Sephadex G-50 column (fine, $2.6 \times 110 \mathrm{~cm}$ ) previously equilibrated with $20 \mathrm{mM}$ Tris- $\mathrm{HCl}$ buffer ( $\mathrm{pH} 7.0$ ) containing $5 \mathrm{mM} \mathrm{CaCl}_{2}$ and was eluted with the same buffer. $O$, absorbance at $280 \mathrm{~nm}$; , protease activity.

of Bacillus sp. N4 strain by ammonium sulfate precipitation and three chromatographic separations as shown in Figs. 2-4. The purification of the protease is summarized in Table 1. The final preparation showed a single protein band on SDS-PAGE (Fig. 5). The apparent molecular weight of N4-protease was estimated to be 28,000 by comparison of its mobility to those of standard proteins with known molecular weights on SDS-PAGE in $12 \%$ gel.

\section{Effect of $p H$}

The maximum activity was found at $\mathrm{pH} 10.0$ toward Suc-Leu-Leu-Val-Tyr-MCA and azocasein and at pH 11.0 toward casein, respectively (Fig.6A). As shown in Fig. 6B, the activity of the enzyme was stable between $\mathrm{pH} 6$ and $\mathrm{pH}$ 11.

\section{Effect of temperature}

The optimum temperature of the protease activity was found to be around $55^{\circ} \mathrm{C}$ in the absence of $\mathrm{CaCl}_{2}$ (Fig. 7A). The optimum was, however, shifted to $65^{\circ} \mathrm{C}$ in the presence of $5 \mathrm{mM} \mathrm{CaCl}$, being accompanied by an increase of about $50 \%$ in the reaction rate. The enzyme was stable up to $50^{\circ} \mathrm{C}$ in the absence of $\mathrm{CaCl}_{2}$ but quickly lost

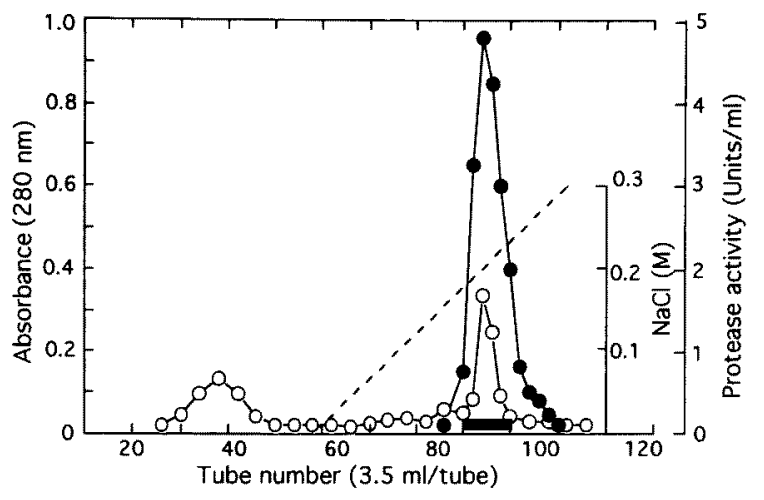

Fig. 3. Ion-exchange chromatography of N4-protease.

The active fractions in Fig. 2 were concentrated and dialyzed against $10 \mathrm{~mm}$ sodium phosphate, $\mathrm{pH} 7.0$. The dialyzate was put on a CM-Toyopearl $650 \mathrm{~S}$ column $(1.6 \times 20 \mathrm{~cm})$ previously equilibrated with the same buffer. The elution was done with a linear gradient of $\mathrm{NaCl}$ in the same buffer. $O$, absorbance at $280 \mathrm{~nm}$;, protease activity.

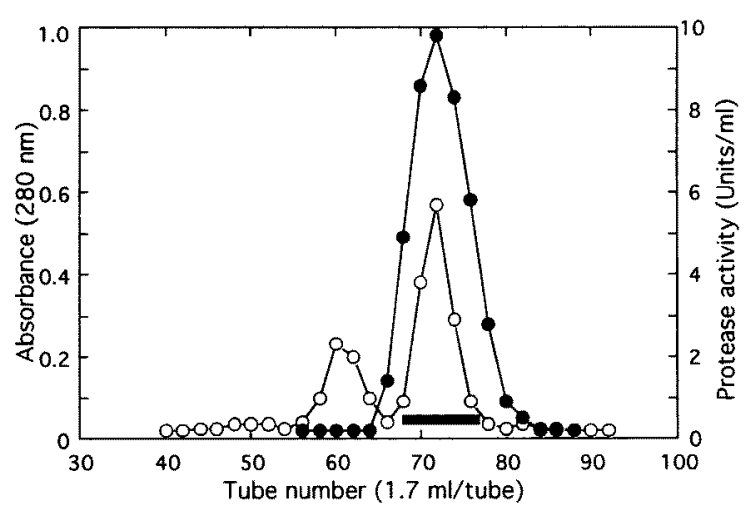

Fig. 4. Gel filtration of N4-protease.

The enzyme $(2 \mathrm{ml})$ was put on a Superdex 75 PG column $(1.6 \times 75$ $\mathrm{cm}$ ) previously equilibrated with $50 \mathrm{~mm}$ Tris- $\mathrm{HCl}$ buffer ( $\mathrm{pH} \mathrm{7.0)}$ containing $5 \mathrm{mM} \mathrm{CaCl}_{2}$ and was eluted with the same buffer. 0 , absorbance at $280 \mathrm{~nm}$; $\bullet$, protease activity.

Table 1. Purification of N4-protease

\begin{tabular}{lrrrrc}
\hline \hline \multicolumn{1}{c}{ Procedure } & $\begin{array}{c}\text { Total } \\
\text { Protein } \\
(\mathrm{mg})\end{array}$ & $\begin{array}{c}\text { Total } \\
\text { unit } \\
(\mathrm{U})\end{array}$ & $\begin{array}{c}\text { Specific } \\
\text { activity } \\
(\mathrm{U} / \mathrm{mg})\end{array}$ & $\begin{array}{c}\text { Recovery } \\
(\%)\end{array}$ & $\begin{array}{c}\text { Purification } \\
\text { (fold) }\end{array}$ \\
\hline Culture fluid & 1764.0 & 4410 & 2.5 & 100 & 1 \\
(NH $\left._{4}\right)_{2} \mathrm{SO}_{4}$ ppt & 43.5 & 3770 & 86.7 & 85.5 & 34.7 \\
Sephadex G-50 & 14.6 & 2427 & 166.2 & 55.0 & 66.5 \\
Toyopearl CM-650 & 8.6 & 2387 & 227.6 & 54.1 & 91.0 \\
Superdex 75 PG & 1.8 & 1509 & 838.3 & 34.2 & 335.3 \\
\hline
\end{tabular}

$90 \%$ of its activity when heated to $60^{\circ} \mathrm{C}$ (Fig. 7B). The enzyme became stable up to $60^{\circ} \mathrm{C}$ in the presence of $5 \mathrm{mM}$ $\mathrm{CaCl}_{2}$ for $1 \mathrm{~h}$ and even at $65^{\circ} \mathrm{C}$ about $50 \%$ of activity remained after $15 \mathrm{~min}$ (data not shown). However, complete inactivation of the enzyme was found at $70^{\circ} \mathrm{C}$ at 15 min in the presence of $\mathrm{CaCl}_{2}$.

\section{Isoelectric point}

As shown in Fig. 8, the isoelectric point for N4-protease 


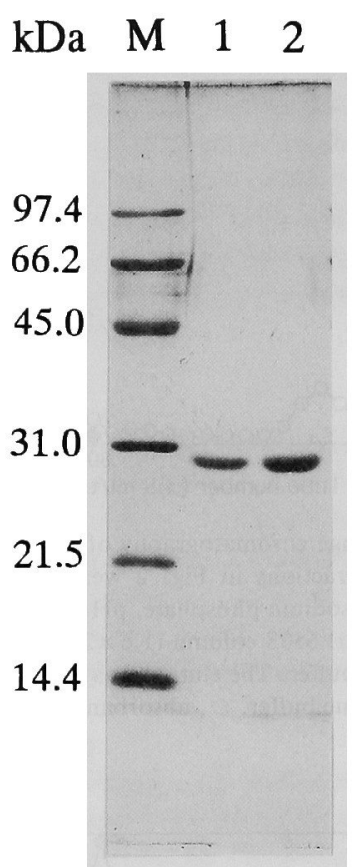

Fig. 5. SDS-PAGE of purified N4-protease.

$\mathrm{M}$, standard proteins; 1, non-reduced N4-protease; 2 , reduced N4protease with 2-mercaptoethanol. The following proteins were used as standards: phosphorylase b $(97,400)$, bovine serum albumin $(66,200)$, ovalbumin $(45,000)$, carbonic anhydrase $(31,000)$, soybean trypsin inhibitor $(21,500)$, and lysozyme $(14,400)$.
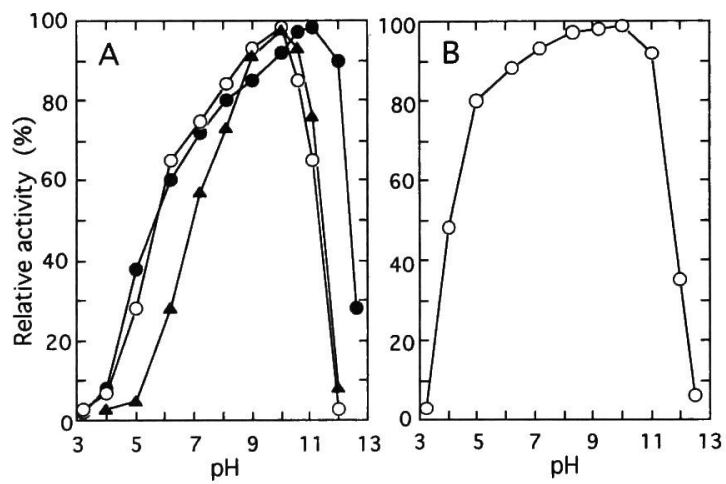

Fig. 6. Effect of pH on the activity and stability of N4-protease.

The optimum $\mathrm{pH}$ of the enzyme was assayed with Carmody's wide-range buffer at $37^{\circ} \mathrm{C}$ for $20 \mathrm{~min}$. For the stability test, the enzyme solutions were incubated with Carmody's wide-range buffer for $1 \mathrm{~h}$ at $24^{\circ} \mathrm{C}$. The remaining activity was assayed by the method in the text. A, pH-activity curve; B, pH-stability curve. Azocasein ( $O$ ), casein $(\bullet)$ and Suc-Leu-Leu-Val-Tyr-MCA $(\boldsymbol{\Delta})$ were used as substrates.

was estimated to be 9.5 by using a Bio-Lad Rotofor apparatus.

\section{Effects of inhibitors and metal ions}

As summarized in Table 2, N4-protease was completely inhibited by the inhibitors of serine protease, PMSF and DFP, but was not affected by sulfhydryl inhibitors including PCMB and NEM and metal chelating agents such as EDTA and EGTA. N4-protease was also inhibited by
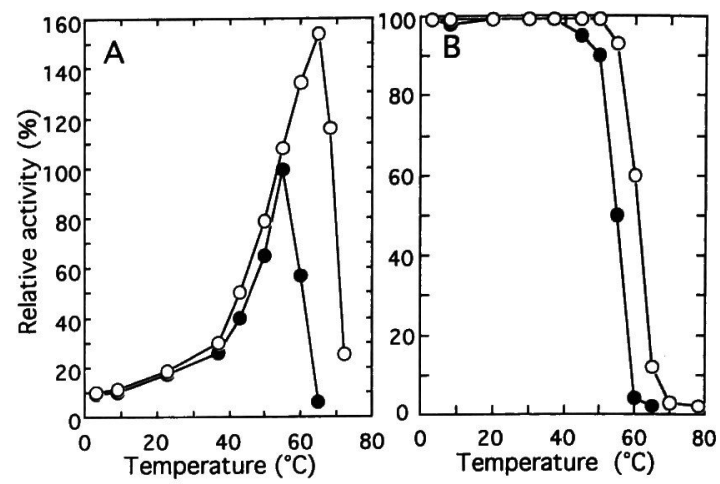

Fig. 7. Effect of temperature on the activity and stability of N4-protease.

The activity was assayed after the incubation of the enzyme for 20 min at various temperatures in $50 \mathrm{~mm}$ sodium carbonate-bicarbonate buffer, $\mathrm{pH}$ 10.0. For the stability test, the enzyme solutions were allowed to stand for $1 \mathrm{~h}$ at various temperatures in the same buffer. The remaining activity was assayed by the method in the text. A, temperature-activity curve; B, temperature-stability curve. $O$, presence of $5 \mathrm{mM} \mathrm{CaCl}_{2} ; \bullet$, absence of $\mathrm{CaCl}_{2}$.

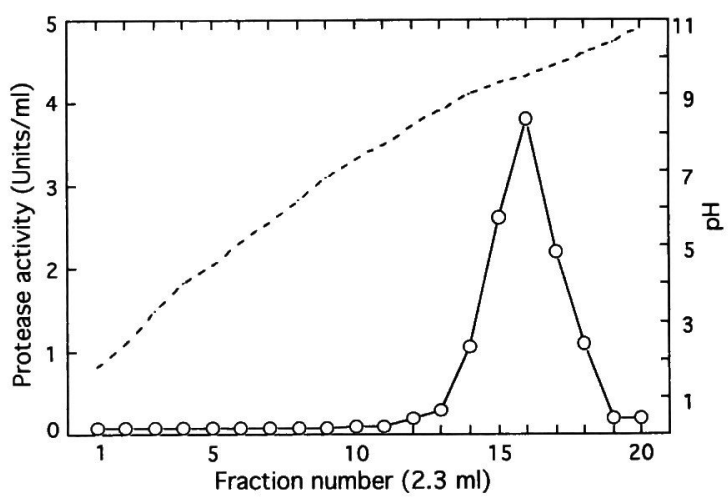

Fig. 8. Estimation of isoelectric point of N4-protease.

Isoelectric focusing was performed with $1 \%$ Pharmalyte $(\mathrm{pH}$ range $3.5-10)$ at $4^{\circ} \mathrm{C}$ for $4 \mathrm{~h}$. $\mathrm{O}$, protease activity; ----, $\mathrm{pH}$ gradient.

Table 2. Effects of inhibitors on the activity on N4-protease

\begin{tabular}{lcc}
\hline Reagents & $\begin{array}{c}\text { Concentration } \\
(\mathrm{mM})\end{array}$ & $\begin{array}{c}\text { Relative activity } \\
\text { (\%) }\end{array}$ \\
\hline Non & 0 & 100 \\
PMSF & 2 & 1.1 \\
& 5 & 0 \\
DFP & 2 & 1.2 \\
& 5 & 0 \\
TPCK & 5 & 32.2 \\
TLCK & 5 & 98.9 \\
& 10 & 59.9 \\
PCMB & 5 & 95.9 \\
NEM & 5 & 98.4 \\
EDTA & 5 & 99.8 \\
& 10 & 103.1 \\
EGTA & 5 & 96.8 \\
& 10 & 100.1 \\
$1,10-P h$ Panthroline & 5 & 101.2 \\
& 10 & 98.9 \\
$\mathrm{ZnCl}_{2}$ & 5 & 32.3 \\
$\mathrm{CdCl}_{2}$ & 5 & 28.3 \\
$\mathrm{HgCl}_{2}$ & 5 & 18.3 \\
\hline
\end{tabular}


$\mathrm{HgCl}_{2}, \mathrm{CdCl}_{2}$, and $\mathrm{ZnCl}_{2}$.

\section{Discussion}

The present report describes an attempt to isolate protease-producing bacteria from the skin mucus of horse mackerel, and to purify and characterize an extracellular protease produced by the isolate Bacillus sp. N4 strain. In general, Bacillus sp. can be isolated from almost all natural habitats such as soil, fresh water, and sea water. Thus it is difficult to determine whether the isolate originates from sea water or other sources.

The protease was easily purified from the culture fluid by three steps of chromatography, and tentatively named N4-protease. The apparent molecular weight of the enzyme was 28,000 by SDS-PAGE and was similar to those of subtilisin BPN', subtilisin Carlsberg, and subtilisin Amylosacchariticus. ${ }^{\text {) }}$

The maximum activity was found at $\mathrm{pH} 10.0$ toward azocasein and Suc-Leu-Leu-Val-Tyr-MCA and at pH 11.0 toward casein, respectively. As shown in Fig. 6B, the activity of the enzyme was stable between pH 6 and $\mathrm{pH} 11$. Values of optimum and stable pHs were almost the same as those of alkaline serine proteases such as subtilisin BPN', subtilisin Carlsberg, subtilisin Amylosacchariticus, subtilisin Natto (B. natto Ns), subtilisin E (B. subtilis 168), and alkaline protease from $B$. mesentericus. ${ }^{6-9)}$

The pI value of N4-protease was 9.5 and this value resembled those of subtilisin Carlsberg, subtilisin Natto, and the protease from alkalophilic Bacillus sp. No. 221, but slightly different from those of subtilisin $\mathrm{BPN}^{\prime}$, subtilisin Amylosacchariticus, and alkaline protease from Bacillus sp. Y. ${ }^{6-10)}$ Thus, Bacillus sp. N4 strain is expected to secrete the alkaline protease belonging to the group of subtilisin Carlsberg.

Endopeptidases are known to be generally classified into four categories. Among them, serine proteases require an essential serine residue for activity and are thus inhibited by hydroxyl-reactive organofluorides such as PMSF and DFP. N4-protease was completely inactivated by PMSF and DFP, indicating that this protease can be classified as a serine protease.)

In general, it has been well known that calcium ion can retard inactivation of enzymes, so the effects of calcium ion on the activity of the protease was investigated. By addition of $\mathrm{Ca}^{2+}, \mathrm{N} 4$-protease was activated and also stabilized at high temperatures (Fig.7). A similar tendency has been observed for those of the alkaline serine proteases from other Bacillus sp. ${ }^{8,9)}$ and from alkalophilic Bacillus sp. No. 221."1)

$\mathrm{Tsuru}^{8,9)}$ has reviewed the comparison of extracellular proteases produced by Bacillus subtilis and the related species. Various strains of Bacillus sp. produce extracellular proteolytic enzymes that have usually been classified, from their $\mathrm{pH}$ activity profile and their susceptibility to inhibitors, into two groups; neutral metal protease and alkaline serine protease. The latter protease is well known as subtilisins. From the results obtained in the present study, it is clear that extracellular N4-protease of Bacillus sp. N4 strain is an alkaline serine protease belonging to a member of the subtilisin family.

In the present study two strains, N4 and N9 (Flavobacterium sp.), were isolated as the most potent producers of protease from horse mackerel skin mucus. Preliminary investigations revealed that strain $\mathrm{N} 9$ produced a unique extracellular metal protease distinct from N4-protease. Additional studies are in progress to characterize the enzymatic properties of the protease produced by strains $\mathrm{N} 4$ and $\mathrm{N} 9$, and to make clear whether strains $\mathrm{N} 4$ and $\mathrm{N} 9$ might be responsible for the spoilage of fishes.

\section{References}

1) J. M. Shewan: The microbiology of sea-water fish, in "Fish as Food", vol. 1, (ed. by G. Borgstrom), Academic Press, New York and London, 1961, pp. 487-560.

2) W. R. Carmody: An easily prepared wide range buffer series. $J$. Chem. Ed., 38, 559-560 (1961).

3) O. H. Lowry, N. L. Rosebrough, A. L. Farr, and R. J. Randall: Protein measurement with the Folin phenol reagent. J. Biol. Chem., 193, 265-275 (1951).

4) U. K. Laemmli: Cleavage of structural proteins during the assembly of the head of bacteriophage T4. Nature, 227, 680-685 (1970).

5) P. H. A. Sneath: Endospore-forming Gram-positive rods and cocci. in "Bergey's Manual of Systematic Bacteriology", vol. 2, (ed. by P. H. A, Sneath, N. S. Mair, M. E. Sharpe, and J. G. Holt), Williams \& Wilkins, Baltimore, 1986, pp. 1104-1207.

6) F. S. Markland, Jr. and E. L. Smith: Subtilisins: Primary structure, chemical and physical properties, in "The enzymes", Vol. 3, (ed. by P. D. Boyer), Academic Press, New York, 1971, pp. 561-608.

7) D. Tsuru and T. Yoshimoto: Microbial proteases, in " CRC Handbook of Microbiology", 2nd ed., vol. 8, (ed. by A. L. Laskin and H. A. Lechevalier), CRC Press, Boca Roton, Florida, 1987, pp. 239-283.

8) D. Tsuru: Proteolytic enzymes of Bacillus species. Biseibutsu, 5, 322-333 (1989) (in Japanese).

9) D. Tsuru: Comparison of extracellular proteases produced by genus Bacillus. Nippon Nogeikagaku Kaishi, 65, 50-55 (1991) (in Japanese).

10) H. Shimogaki, K. Takeuchi, T. Nishino, M. Ohdera, T. Kudo, K, Ohba, M. Iwama, and M. Irie: Purification and properties of a novel surface-active agent- and alkaline-resistant protease from Bacillus sp. Y. Agric. Biol. Chem., 55, 2251-2258 (1991).

11) K. Horikoshi: Production of alkaline enzymes by alkalophilic microorganisms. Part I. Alkaline protease produced by Bacillus No. 221. Agr. Biol. Chem., 35, 1407-1414 (1971). 